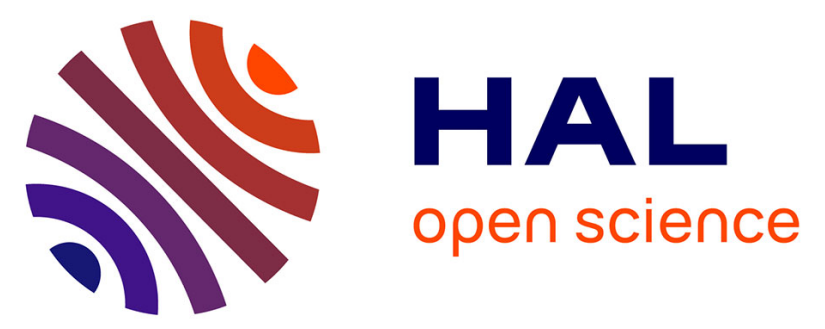

\title{
GROWTH OF THIN ALUMINA FILM ON ALUMINIUM AT ROOM TEMPERATURE: A KINETIC AND SPECTROSCOPIC STUDY BY SURFACE PLASMON EXCITATION
}

\author{
P. Dumas, J. Dubarry-Barbe, D. Rivière, Yves Levy, J. Corset
}

\section{To cite this version:}

P. Dumas, J. Dubarry-Barbe, D. Rivière, Yves Levy, J. Corset. GROWTH OF THIN ALUMINA FILM ON ALUMINIUM AT ROOM TEMPERATURE: A KINETIC AND SPECTROSCOPIC STUDY BY SURFACE PLASMON EXCITATION. Journal de Physique Colloques, 1983, 44 (C10), pp.C10-205-C10-208. 10.1051/jphyscol:19831042 . jpa-00223499

HAL Id: jpa-00223499 https://hal.science/jpa-00223499

Submitted on 1 Jan 1983

HAL is a multi-disciplinary open access archive for the deposit and dissemination of scientific research documents, whether they are published or not. The documents may come from teaching and research institutions in France or abroad, or from public or private research centers.
L'archive ouverte pluridisciplinaire HAL, est destinée au dépôt et à la diffusion de documents scientifiques de niveau recherche, publiés ou non, émanant des établissements d'enseignement et de recherche français ou étrangers, des laboratoires publics ou privés. 


\title{
GROWTH OF THIN ALUMINA FILM ON ALUMINIUM AT ROOM TEMPERATURE : A KINETIC AND SPECTROSCOPIC STUDY BY SURFACE PLASMON EXCITATION
}

\author{
P. Dumas, J.P. Dubarry-Barbe, D. Rivière ${ }^{*}$, Y L Levy $^{*}$ and J. Corset \\ Laboratoire de Spectrochimie Infrarouge et Raman, 2, me Henri Dunant, \\ 94320 Thiais, France \\ * Institut d'optique, Centre d'orsay, 91406 Orsay, Fronce
}

Résumé : Les paramètres cinētiques, ainsi que l'êpaisseur limite de l'alumine formée par oxydation de 1 'a luminium, à température et à pression ambiantes, ont été détermi nées par la technique de réflexion totale attënuée. Le film d'oxyde crốt rapidement et atteint une épaisseur limite de $32 \AA$ après 10 minutes d'exposition à 1 'air. Des temps d'exposition ul térieurs $n$ 'entrainent qu'une faible augmentation de 7 'épaisseur de 7 'alumine (environ $40 \AA$ après trois mois d'exposition). Une étude par spectroscopie Raman révè le la présence d'entités $\mathrm{OH}$ à la surface de l'alumine, dont les fréquences de vibration sont identiques à celles enregistrées pour des $\mathrm{OH}$ adsorbés sur de 7 'alumine $\boldsymbol{Y}$. Par contre, aucun signal Raman pouvant être attribué à 1 'alumine n'a étê observê.

Abstract : The kinetic parameters and the limiting thickness of alumina formed on an a luminium film, at room temperature, under ambient pressure, can be determined by using an attenuated total reflection experimental set-up. An oxide 1ayer growths rapidly and reaches a limiting thickness of about $32 \AA$ after 10 minutes of exposure. Longer exposure time leads to a slow increase (about $40 \AA$ after three months). Raman spectroscopic investigation reveals the presence of $\mathrm{OH}$ surface groups at the same frequency position as those observed on.y-alumina. No vibrational bands of the aluminium oxide was detected.

\section{INTRODUCTION}

The kinetic of the low temperature oxidation of aluminium has been studied by a variety of techniques such as scanning high energy electron diffraction $/ 1 /$, work function measurements $/ 2 /$, infrared reflectance spectroscopy $/ 3 /$, ellipsometric measurements $/ 4 / \ldots$ It seems to be accepted that the kinetic of formation of the oxide layer follows a logarithmic law /5\%. The model of the growing process suggests that oxygen ions rapidly exchange place with aluminium atoms at the surface during the initial stage of the reaction. After monolayer coverage, the sticking coefficient of oxygen drops rapidly, and then normal chemisorption of oxygen on the stable amorphous oxide layer occurs. The oxide continues to grow by an ionic diffusion mechanism. As revealed by the literature date, the oxide reaches a limiting thickness of 15-50 $\AA$. Because the surface plasma wave is a sensitive probe of metallic surfaces, its propagation is influenced by any modification occurring at the dielectric-metal interface. Furthermore, it was first pointed out by Chen et a1. /6/ that the enhancement of the electric field at the metal surface, at the surface plasmon resonance, could be used to enhance the Raman signals from overlayers.

In this study, the oxidation of aluminium at room temperature, under ambient pressure, was investigated using an attenuated total reflection (ATR) experimental arrangement.

\section{EXPERIMENTAL}

Under high vacuum conditions, an aluminium film was deposited on a prism, with an evaporation rate of $5 \AA / \mathrm{s}^{-1}$. The thickness of the film was monitored using a quartz microbalance.

For kinetic investigation, $190 \AA$ of aluminium was deposited on a CaF 2 prism. This thickness was calculated to obtain optimum resonance conditions in the UV region. After the evaporation, the prism was rapidly exposed to air, and located at the center 
of a rotating stage, connected to microcomputer monitors. The angular position of the reflectivity minimum $\left(\theta_{\min }\right)$, in p-polarization, (see insert in fig. 1 ) was recorded as a function of the time exposure. The first measurement was done about one minute after the introduction of air in the vacuum vessel. The incoming beam into the prism originated from a He-Ne laser.

For spectroscopic study, a $3638 \AA$ I ine of an argon laser was used, together with a double monochromator spectrometer having holographic gratings (1200 lines/mn, Ramanor HG-2S, Jobin-Yvon). Spectra recordings were monitored by a computer system, allowing accumulations in order to increase the signal to noise ratio.

\section{RESULTS AND DISCUSSION}

Figure 1 shows the dependence of the angular position of the reflectivity minimum $\left(\theta_{\min }\right)$ with the exposure time to the $\operatorname{air}\left(\lambda=6328 \AA, \mathrm{d}_{\mathrm{Al}}=190 \AA, \mathrm{n}_{\mathrm{CaF} 2}=1.433\right)$. After about ten minutes exposure, the value of $\theta_{\text {min }}$ tends to stabilize, thus allowing the recording of the reflectivity curve over a wide angular range (Figure 2).

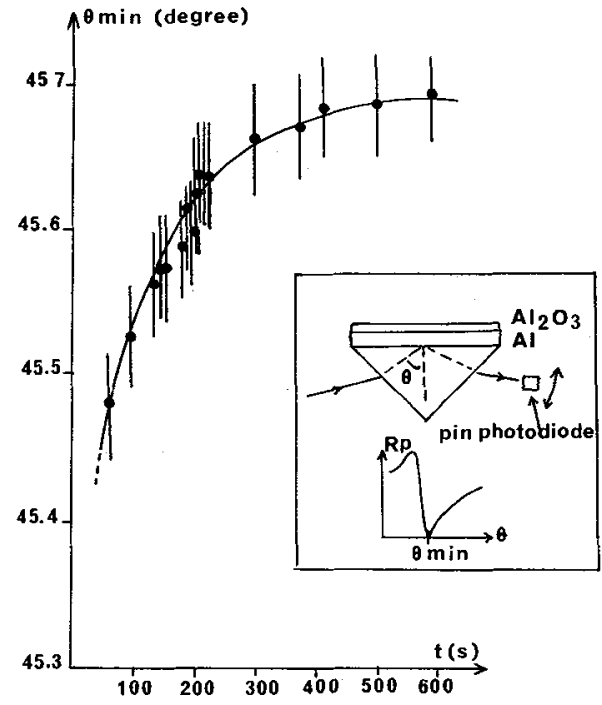

Fig. 1- Dependence of the angular position of the reflectivity minimum, $\theta_{\text {min }}$, versus the time exposure to air. $\left(\lambda=6328 \AA, n_{\mathrm{CaF} 2}=1.433\right.$; thickness of the evaporated aluminium $=190 \AA$ )

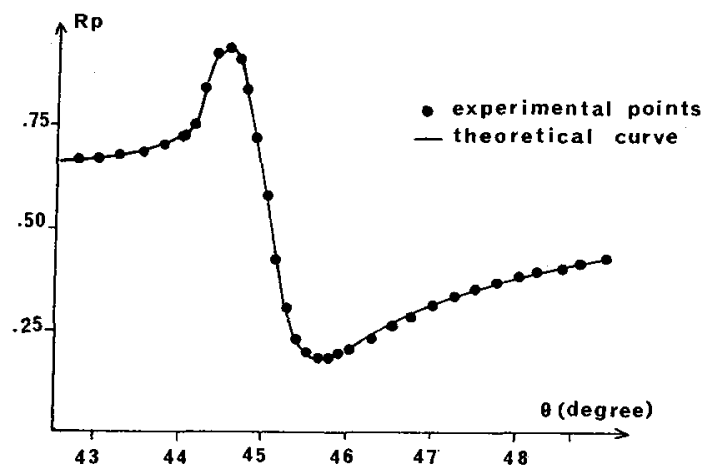

Fig. 2- Attenuated total reflectivity curve after 60 minutes exposure to air. Symbols are experimental points, and the solid Tine corresponds to the theoretical curve.

Note, on the reflectivity curve reported in figure 2, that the reflectivity Rp does not fall to zero because the thickness of the deposited aluminium was optimized for a minimum of $R p\left(R_{\min }\right)$ in the UV region. NevertheTess, the relative high value of $R_{\text {min }}$ may serve as a measurable parameter of the alumina growth $/ 7 /$.

The oxide growths rapidiy during the initial stage of the reaction. So, even if theoretical predictions suggest a logarithmic growth 1 aw $/ 5 /$, it seems difficult to distinguish experimentally the Togarithmic from the parabolic laws. So, we have reported on figure 3 the dependence of $\theta_{\min }$ versus $t^{1 / 2}$. The 7 inear dependence observed up to about 7 minutes, permits the estimation of the $\theta_{\min }$ angular value at $t=0$, i.e. for the pure aluminium film. Such an information cannot be obtained directly in our experimental conditions.

Because the $\theta_{\min }$ angular shift is due to the simultaneous increase of alumina $d_{A_{2} \mathrm{O}_{3}}$ and decrease of aluminium $d_{A 1}$ thicknesses, in the calculation of $d_{A 12} \mathrm{O}_{3}$, we 


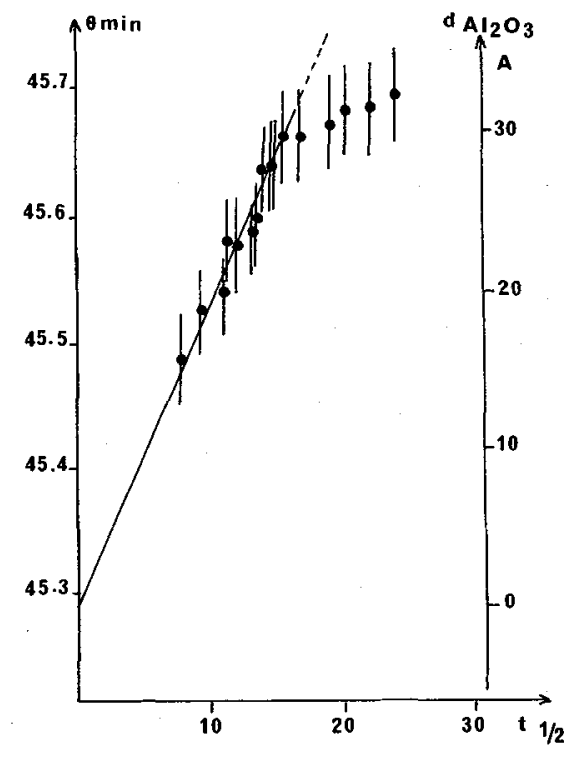

Fig. 3- Plot of $\theta_{\min }$ versus $t^{1 / 2}$ Note the fast increase of the alumina thickness during the first stage of the oxidation process, and the linear dependence of $\theta_{\text {min }}$ with $t^{1 / 2}$ up to about $7 \mathrm{mn}$. The corresponding calculated values of $\mathrm{dAl}_{2} \mathrm{O}_{3}$ are also reported (see text)

have estimated, from their relative density, that the ratio of alumina thickness over the loss of aluminium thickness was 1.6 . We have shown /7/ that a good theoretical fit of the experimental reflectivity curve allows the determination of $d_{A 1203}$ and $\varepsilon_{A}$ ( $\varepsilon=$ dielectric constant), if the refractive index of the alumina layer $\left(\mathrm{n}_{\mathrm{A}} \mathrm{I}_{2} \mathrm{O}_{3}\right)$ is known. In this experiment, we have supposed that $n_{\mathrm{A} 120_{3}}=1.7$.

A good fit is obtained (figure 2 ) with : $d_{A 120_{3}}=35 \AA ; d_{A 7}=166 \AA$ and $\varepsilon_{A T}=-42.3+21$ i (at $\left.\lambda=6328 \AA\right)$.

The calculated value of $\varepsilon_{A 1}$ is in good agreement with those reported by Mathewson and Myers $18 \%$. The so-calculated dielectric constant is of prime importance for the interpretation of the $\theta_{\min }$ angular shifts during the oxide growing process.

From our results, we can estimated that the $\theta_{\text {min }}$ angular variation of 0.4 degree corresponds to the formation of $32 \AA$ of alumina.

The recording of the reflectivity curve after three months exposure to air indicates that the alumina layer continues to grow and reaches a limiting thickness of about $40 \AA$.

The vibrational properties of the oxide film were tentatively investigated by Raman spectroscopy, with an exciting wavelength of $3638 \AA$. The diffuse Raman light was collected in a direction perpendicular to the surface (see insert figure 4). Due to the values of its dielectric constants, surface plasma waves of aluminium can be excited in the UV. This aspect is interesting in the case of spectroscopic study because of the $\nu^{4}$ dependence of the Raman intensity ( $\nu=$ frequency of the incident 1ight).

The optimum incident angle for this study was chosen about 0.5 degree before $\theta_{\text {min }}$ because the maximum amplitude of the surface plasma waves doesn't correspond with the minimum intensity of the reflected beam $/ 9 \%$.

All our attempts to observe Raman bands from the aluminium oxide were unsuccessful . Nevertheless, two bands located at $3697 \mathrm{~cm}^{-1}$ and $3795 \mathrm{~cm}^{-1}$ were observed, after 100 accumulations (figure 4). These bands disappear when rotating the polarization of the incident light, or after a small change of the incident angle.

We have assigned these Raman bands to $\mathrm{OH}$ groups bounded to alumina. Perri et al. $110 /$ have reported infrared absorption bands of $\mathrm{OH}$-bounded $\gamma$-alumjna, located at the same frequencies, but an additional band was observed at $3737 \mathrm{~cm}^{-1}$ on their spectrum. This band is not seen in our case, but it may be a shoulder of the $3697 \mathrm{~cm}^{-1}$ one. So, we suggest that the alumina films have a $\gamma$-alumina superficial structure. 


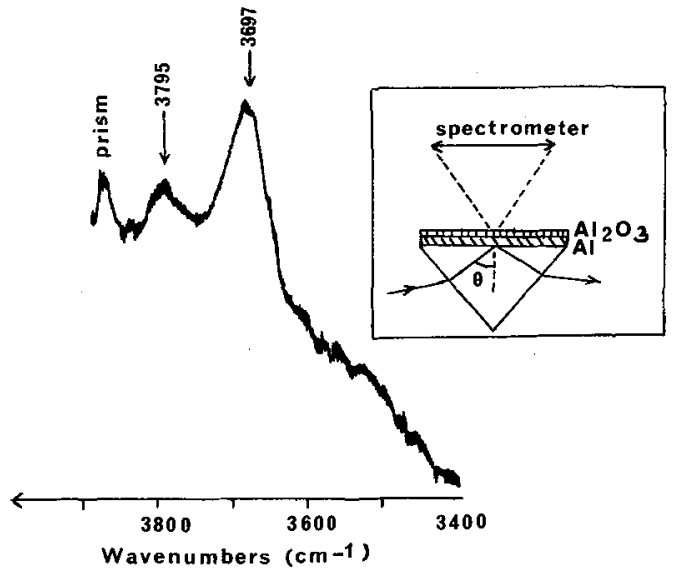

Fig. 4- Raman spectrum of $\mathrm{OH}$ groups bounded to alumina, after 100 accumulations, between 3400 and $3900 \mathrm{~cm}^{-1}$. $\left(\lambda=3638 \AA, 300 \mathrm{~mW}\right.$ power, $6 \mathrm{~cm}^{-1}$ slit width, p-polarized light).

The observation of $\mathrm{OH}$ vibrational bands under excitation of surface plasmon by ATR is surprising, if one considers that attempts to obtain Raman spectrum from adsorbed molecules on silver films, by ATR techniques, were unsuccessful. An additional resonance contribution may be suggested in our case, because we were not able to detect any Raman signal of pyridine and formic acid adsorbed on the thin alumina film.

\section{CONCLUSION}

Attenuated total reflection is a useful technique to investigate the kinetic of formation of a thin alumina layer on an aluminium film. It may be applied to other relatively slowly evoluting systems. For spectroscopic study of adsorbed molecules on alumina, further experiments are needed to clarify the possibilities of such an arrangment.

\section{REFERENCES}

/1/-J.M. KHAN, D.M. MAKOWIECKI Surface Sci. 77, (1978), L155.

/2/-C.T. KIRK Jr, E.E. HUBER Jr Surface SCi. 9, (1968), 217.

/3/-F.P. MERTENS Surface Sci. 71, (1978), 161.

/4/-B.E. HAYDEN, W. WYROBISCH, W. OPPERMAN, S. HACHICHA, P. HOFMANN, A.M. BRADSHAW Surface Sci. 109, (1981), 207.

/5/-F.P. FEHLER, N.F. MOTT 0xid. of Metals 2 , (1970), 59.

/6/-Y.J. CHEN, W.P. CHEN, E. BURNSTEIN Phys. Rev. Letters 36, (1976), 1207.

/7/-J.P. DUBARRY-BARBE, D. RIVIERE, P. DUMAS, Y. LEVY, J. CORSET to be published.

/8/-A.G. MATHEWSON, H.P. MYERS Phys. Scripta $\underline{4}$, (1971), 291.

19/-J.C. DUDEK, G. HINCELIN C. R. Acad. Sci. Paris, B, 286, (1978), 257 and references therein.

/10\%-J.B. PERRI, R.B. HANNAN J. Phys. Chem. 64, (1960), 1526. 